\title{
Theoretical study of the possibility of glycin with thiotriazoline complexes formation
}

\author{
L. I. Kucherenko ${ }^{1,2}$, O. V. Khromyleva ${ }^{1}$, I. A. Mazur ${ }^{1,2}$, S. V. Shishkina ${ }^{2}$
}

${ }^{1}$ Zaporizhzhia State Medical University, Ukraine, ${ }^{2}$ SPA «Farmatron», Zaporizhzhia, Ukraine

Brain strokes are widely spread all over the world and are among the most dangerous for the population. Often it leads to death, complete or partial loss of ability to work. The correction of imbalance of Excitatory and inhibitory neurotransmitter systems by activation of natural inhibitory processes is a promising direction of primary neuroprotection in cerebral ischemia. Particular attention is drawn to the natural inhibitory neurotransmitter - glycine and its role in the mechanisms of acute cerebral ischemia. There are data on the ability of the thiotriazoline antioxidant to potentiate the therapeutic effect of neurometabolic cerebroprotectors. Therefore, the creation of new combined preparation based on glycine with thiotriazoline is important today.

Objective: to study the structure, and estimate the energy of formation and geometric characteristics of the intermolecular hydrogen bonds for complexes which are formed with glycine, 3-methyl-1,2,4-triazolyl-5-thioacetate (MTTA) and morpholine.

Method of calculation. The initial approximation to the structure of the complexes was obtained with the help of molecular docking procedure using the AutoDock Vina program. The resulting three-component complexes were preliminarily optimized by the semiempirical PM7 method, taking into account the outward influences, which was simulated by the COSMO method. The calculations were carried out using the MOPAC2012 program. The complexes were optimized using the density functional method with the empirical dispersion correction B97-D3/SVP+COSMO (Water) using geometric correction for the incompleteness of the gCP basic set. A more accurate calculation of the solvation energy was carried out by SMD method. Calculations by the density functional method were carried out using the ORCA 3.0.3 program. The energy of formation of complexes in solution was calculated as the difference between the free Gibbs energies of the solvated complex and its individual solvated components.

Results and its discussion. Quantum-chemical modeling of the complexes of thiatriazoline and glycine has showed the possibility of the formation of multiple hydrogen bonds in them. The results of calculations show that the multiplicity of charge-enhanced donor and acceptor sites for hydrogen bonding leads to the formation of complexes that are different in structure but close in energy formation.

Conclusions. The conducted quantum-chemical study of system has shown the possibility of formation of three-component complexes with low stability in infinitely diluted solutions. The glycine molecule tends to form not only intermolecular hydrogen bonds, but also a charge-enhanced intramolecular hydrogen bond. It can be expected that in real solutions the enhancement of intermolecular interactions can lead to an increase in the stability of the complexes.

\section{Теоретичне дослідження можиивості утворення комплексів гліцину з тіотриазоліном}

А. І. Кучеренко, О. В. Хромильова, І. А. Мазур, С. В. Шишкіна

Мозкові інсульти доволі широко поширені в усьому світі та є одними з найнебезпечніших для населення. Нерідко вони завершуються летально, повною або частковою втратою працездатності. При церебральній ішемії перспективним напрямом первинної нейропротекції є корекція дисбалансу збудливих і гальмівних нейротрансмітерних систем за допомогою активації природних гальмівних процесів. Особливу увагу привертає природний гальмівний нейротрансмітер гліцин і його роль у механізмах гострої церебральної ішемії. $€$ дані про здатність антиоксиданту тіотриазоліну потенціювати терапевтичну дію нейрометаболічних церебропротекторів. Тому актуальним є створення нового комбінованого препарату на основі гліцину з тіотриазоліном.

Мета роботи - вивчити будову, оцінити енергію створення та геометричні характеристики водневих зв'язків для комплексів, що утворені гліцином, 3-метил-1,2,4-триазоліл-5-тіоацетатом (MTTA), морфоліном.

Методика розрахунків. Початкове наближення до будови комплексів отримано за допомогою процедури молекулярного докінгу з використанням програми AutoDock Vina. Одержані трикомпонентні комплекси були попередньо оптимізовані напівемпіричним методом PM7 з урахуванням впливу середовища, яке моделювали в рамках методу COSMO. Розрахунки виконали за допомогою програми МОРАС2012. Потім комплекси були оптимізовані методом функціонала щільності з емпіричною дисперсійною поправкою B97-D3/SVP + COSMO (Water) із застосуванням геометричної поправки на неповноту базисного набору gCP. Точніший розрахунок енергії сольватації здійснили методом SMD. Розрахунки методом фуннкціонала щільності - за допомогою програми ORCA 3.0.3. Енергія утворення комплексів у розчині розраховувалась як різниця вільних енергій Гіббса сольватованих комплексів і сольватованих окремих його компонент.

Результати. Квантово-хімічне моделювання комплексів тіотриазоліну та гліцину показало можливість утворення в них множинних водневих зв'язків. Результати розрахунків свідчать, що множинність зарядово-посилених донорних та акцепторних сайтів для водневого зв'язування призводить до утворення комплексів різних за будовою, але близьких за енергією створення.

Висновки. Квантово-хімічне дослідження системи показало можливість утворення трикомпонентних комплексів із невисокою стабільністю в нескінченно розведених розчинах. Молекула гліцину схильна утворювати не тільки міжмолекулярні водневі зв'язки, а й зарядово-посилений внутрішньомолекулярний водневий зв'язок. Можна очікувати, що в реальних розчинах посилення міжмолекулярних взаємодій може призвести до збільшення стабільності комплексів. 
Кмючевые слова:

глицин,

тиотриазолин,

квантово-

химические

расчеты,

молекулярные

комплексы.

Запорожский

медицинский

журнал. - 2017. -

T. 19, № 5(104). -

C. $675-679$

\title{
Теоретическое исследование возможности образования комплексов глицина с тиотриазолином
}

\begin{abstract}
А. И. Кучеренко, О. В. Хромылёва, И. А. Мазур, С. В. Шишкина
Мозговые инсульты достаточно широко распространены во всём мире и являются одними из наиболее опасных для населения. Нередко они заканчиваются летально, полной или частичной потерей трудоспособности. При церебральной ишемии перспективным направлением первичной нейропротекции является коррекция дисбаланса возбуждающих и тормозных нейротрансмиттерных систем с помощью активации естественных тормозных процессов. Особое внимание привлекает естественный тормозной нейротрансмиттер глицин и его роль в механизмах острой церебральной ишемии. Имеются данные о способности антиоксиданта тиотриазолина потенцировать терапевтическое действие нейрометаболических церебропротекторов. Поэтому актуальным является создание нового комбинированного препарата на основе глицина с тиотриазолином.
\end{abstract}

Цель работы - изучить строение, оценить энергию образования и геометрические характеристики межмолекулярных водородных связей для комплексов, образованных глицином, 3-метил-1,2,4-триазолил-5-тиоацетатом (МТTА) и морфолином.

Методика расчётов. Начальное приближение к строению комплексов получено с помощью процедуры молекулярного докинга с использованием программы AutoDock Vina. Полученные трёхкомпонентные комплексы были предварительно оптимизированы полуэмпирическим методом PM7 с учётом влияния среды, которую моделировали в рамках метода COSMO. Расчёты проводились с помощью программы MOPAC2012. Затем комплексы были оптимизированы методом фуннционала плотности с эмпирической дисперсионной поправкой B97-D3/SVP+COSMO (Water) с применением геометрической поправки на неполноту базисного набора gСР. Более точный расчёт энергии сольватации был проведён методом SMD. Расчёты методом функционала плотности проведены с помощью программы ORCA 3.0.3. Энергия образования комплексов в растворе рассчитывалась как разница свободных энергий Гиббса сольватированного комплекса и сольватированных отдельных его компонент.

Результаты. Квантово-химическое моделирование комплексов тиотриазолина и глицина показало возможность образования в них множественных водородных связей. Результаты расчётов свидетельствуют о том, что множественность зарядово-усиленных донорных и акцепторных сайтов для водородного связывания приводит к образованию комплексов, разных по строению, но близких по энергии образования.

Выводы. Квантово-химическое исследование системы показало возможность образования трёхкомпонентных комплексов с невысокой стабильностью в бесконечно разбавленных растворах. Молекула глицина склонна образовывать не только межмолекулярные водородные связи, но и зарядово-усиленную внутримолекулярную водородную связь. Можно ожидать, что в реальных растворах усиление межмолекулярных взаимодействий может привести к увеличению стабильности комплексов.

Brain strokes are widely spread all over the world and are among the most dangerous for the population. Often it leads to complete or partial loss of ability to work, significant decrease in the quality of life of patients. Therefore, it is extremely important to prevent the death of nerve cells, to protect them from damage in ischemia, to restore impaired blood supply in pathological changes in the circulation.

The correction of imbalance of excitatory and inhibitory neurotransmitter systems by activation of natural inhibitory processes is a promising direction of primary neuroprotection in cerebral ischemia. Particular attention is drawn to the natural inhibitory neurotransmitter - glycine and its role in the mechanisms of acute cerebral

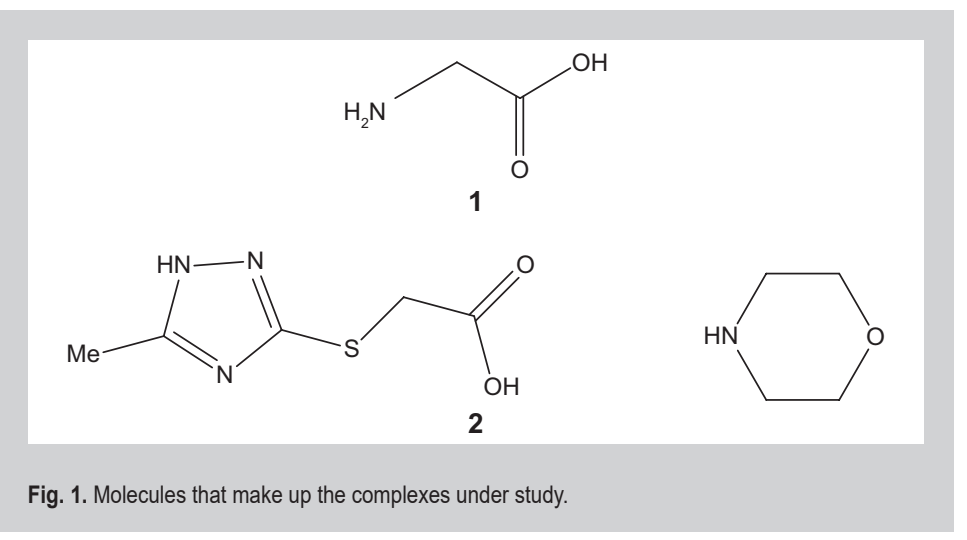

ischemia [1]. Glycine has inhibitory properties not only due to the interaction with its own glycine receptors, but also with the GABA receptors. Glycine is also a coagonist of glutamate NMDA receptors and it is necessary for their normal functioning in submicromolecular concentrations. Activation of these receptors is possible only under the condition of binding of glycine with specific, insensitive to strychnine, glycine sites. There are data on the ability of the thiotriazoline antioxidant to potentiate the therapeutic effect of neurometabolic cerebroprotectors.

Therefore, it is urgent to create a new combined preparation based on glycine (1) with thiotriazoline (2) (Fig. 1).

Objective: to study the structure, and estimate the energy of formation and the geometric characteristics of the intermolecular hydrogen bonds for complexes formed with glycine, 3-methyl-1,2,4-triazolyl-5-thioacetate (MTTA) and morpholine.

\section{Method of calculation}

Modeling of the structure and stability of glycine complexes with thiotriazoline was carried out by procedure that is similar to that used earlier in the study of isoniazid complexes with thiotriazoline [2].

The initial approximation to the complexes structure was obtained with the help of molecular docking procedure using the AutoDock Vina program [3]. The docking of ICCA and morpholine was conducted to construct ternary com- 
plexes in the first stage; then according to the results, 50 structures with lowest energy were selected. Further docking of the complexes of MTA and morpholine with amino acid molecules was carried out, and 50 most stable structures were also selected. This procedure was carried out for each of the possible tautomeric forms of the three-component complexes. As a result, 2500 initial structures were obtained for each of the complexes.

In the second stage, the obtained three-component complexes were preliminarily optimized by the semiempirical PM7 method, taking into account outward influences, which was simulated by the COSMO method. Calculations were carried out using MOPAC2012 program [4]. According to the results of calculations for each of the complexes there have been selected 100 most low-lying energy structure, which were then optimized using the density functional empirical dispersion correction B97-D3/ SVP+COSMO (Water) [5-8] using geometric correction for incomplete $\mathrm{gCP}$ basic set [9]. 10 most energy stable have been selected from the obtained structures of ternary complexes; then the final calculation of geometry and thermodynamic parameters were held in a rigid rotor approximation method B97-D3/TZVP+COSMO. A more accurate calculation of the solvation energy was carried out by the SMD method [10]. The calculations by density functional method were carried out using the ORCA software 3.0.3 [11]. The energy of complex formation in the solution was calculated as the difference of the Gibbs free energies of the complex solvated and its individual solvated components.

The chosen technique, which relies on the study of the complete conformational space of complexes by molecular docking methods and a series of sequential quantum chemical calculations using increasingly higher methods, guarantees probability of the most stable three-component complexes.

\section{Results and discussion}

The study of the structure of thiotriazoline by X-ray diffraction method [12] has showed that this compound is an organic salt. The carboxyl group of MTTA is quite easily deprotonated, becoming negatively charged, and the morpholine nitrogen atom is protonated, obtaining a positive charge. The third component of the system under study, glycine, exists in the crystal as a zwitterionic form. Thus, the system under study contains two deprotonated carboxyl groups, protonated amino group, protonated morpholine, which are capable to participate in formation of intermolecular charge-assisted hydrogen bonds. In addition, the triazole cycle can be both proton donor and acceptor, forming somewhat weaker hydrogen bonds.

It can be assumed that the multiplicity of possible donors and proton acceptors creates conditions for the variability of intermolecular hydrogen bonds (Fig. 2). As a result, there are prerequisites for the formation of polymorphic modifications due to the possibility of the existence of complexes of molecules under study with very similar formation energy. An additional argument in favor of this conclusion is that two polymorphic modifications of thiatrizoline [12] and four polymorphic modifications of glycine were found by X-ray diffraction analysis [13].

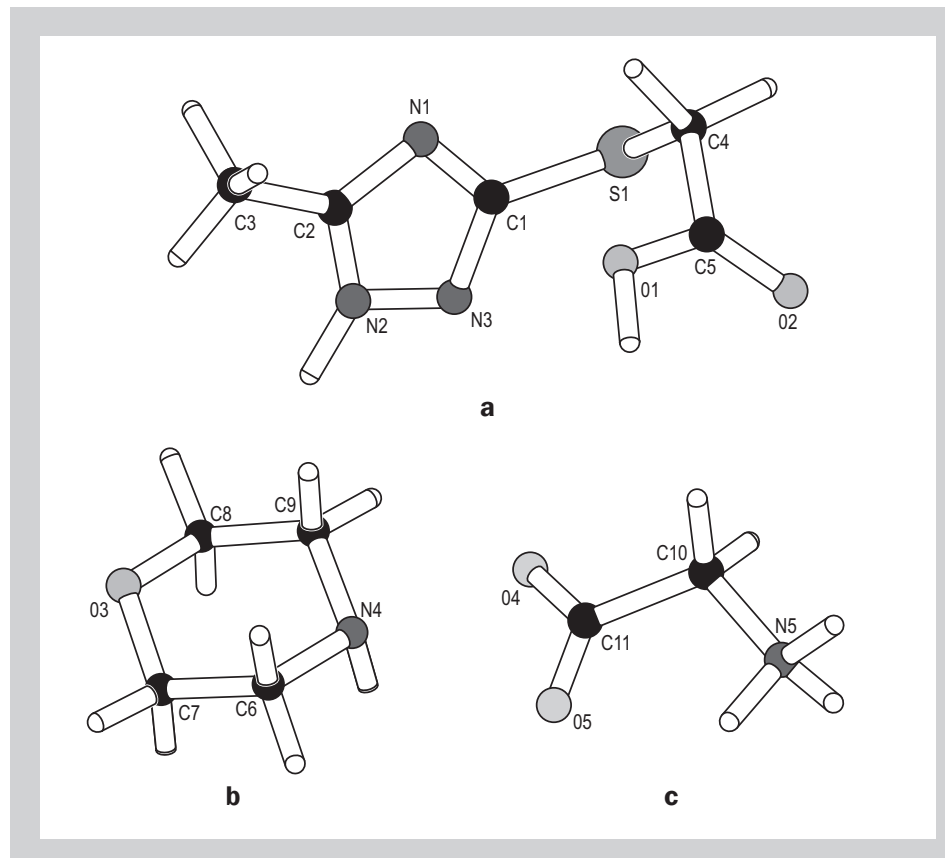

Fig. 2. The structure of the molecules of thiatriazoline $(a-b)$ and glycine (c) with atomic numbering.

Table 1. The structure of the most stable complexes with thiatriazoline and glycine, their formation energies $(\mathrm{kcal} / \mathrm{mol})$ and hydrogen bond characteristics $(\mathrm{H}$... $\mathrm{A}, \AA$ and D-H...A, deg) according to the method of B97-D3/TZVP+SMD (Water)
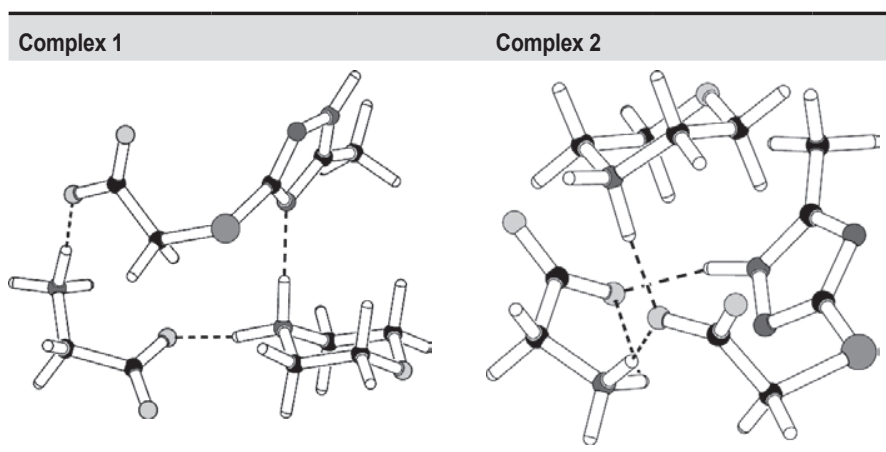

$\Delta \mathrm{G}_{\text {form }}^{298}=6.6 \mathrm{kcal} / \mathrm{mol}$ $\Delta \mathrm{G}_{\mathrm{form}}^{298}=6.9 \mathrm{kcal} / \mathrm{mol}$

\begin{tabular}{llllll} 
N4-H...O4 & 1.61 & 170 & N2-H...O5 & 1.80 & 150 \\
N4-H...N1 & 1.81 & 176 & N4-H...01 & 1.62 & 173 \\
N5-H...01 & 1.57 & 175 & N5-H...01 & 1.65 & 169 \\
& & & N5-H...O5 & 2.16 & 112 \\
\hline
\end{tabular}

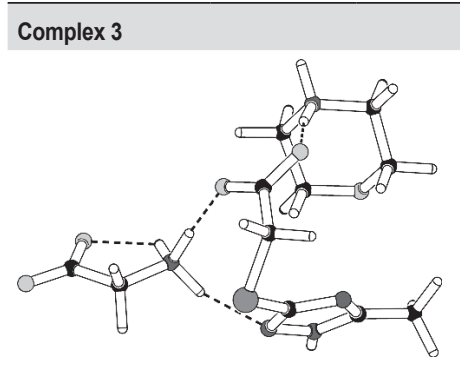

Complex 4

$\Delta \mathrm{G}_{\text {form }}^{298}=8.3 \mathrm{kcal} / \mathrm{mol}$

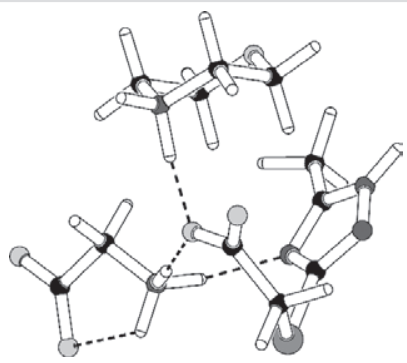

$\begin{array}{llllll}\text { N4-H...O1 } & 1.60 & 170 & \text { N4-H...O2 } & 1.63 & 171 \\ \text { N5-H...O2 } & 1.68 & 173 & \text { N5-H...O2 } & 1.77 & 164 \\ \text { N5-H...O5 } & 1.94 & 120 & \text { N5-H...N3 } & 1.92 & 152 \\ \text { N5-H...N3 } & 1.98 & 152 & \text { N5-H...O4 } & 2.04 & 115\end{array}$


Table 1. The structure of the most stable complexes with thiatriazoline and glycine, their formation energies $(\mathrm{kcal} / \mathrm{mol})$ and hydrogen bond characteristics $(\mathrm{H} . . . \mathrm{A}, \AA$ and D-H...A, deg) according to the method of B97-D3/TZVP+SMD (Water)
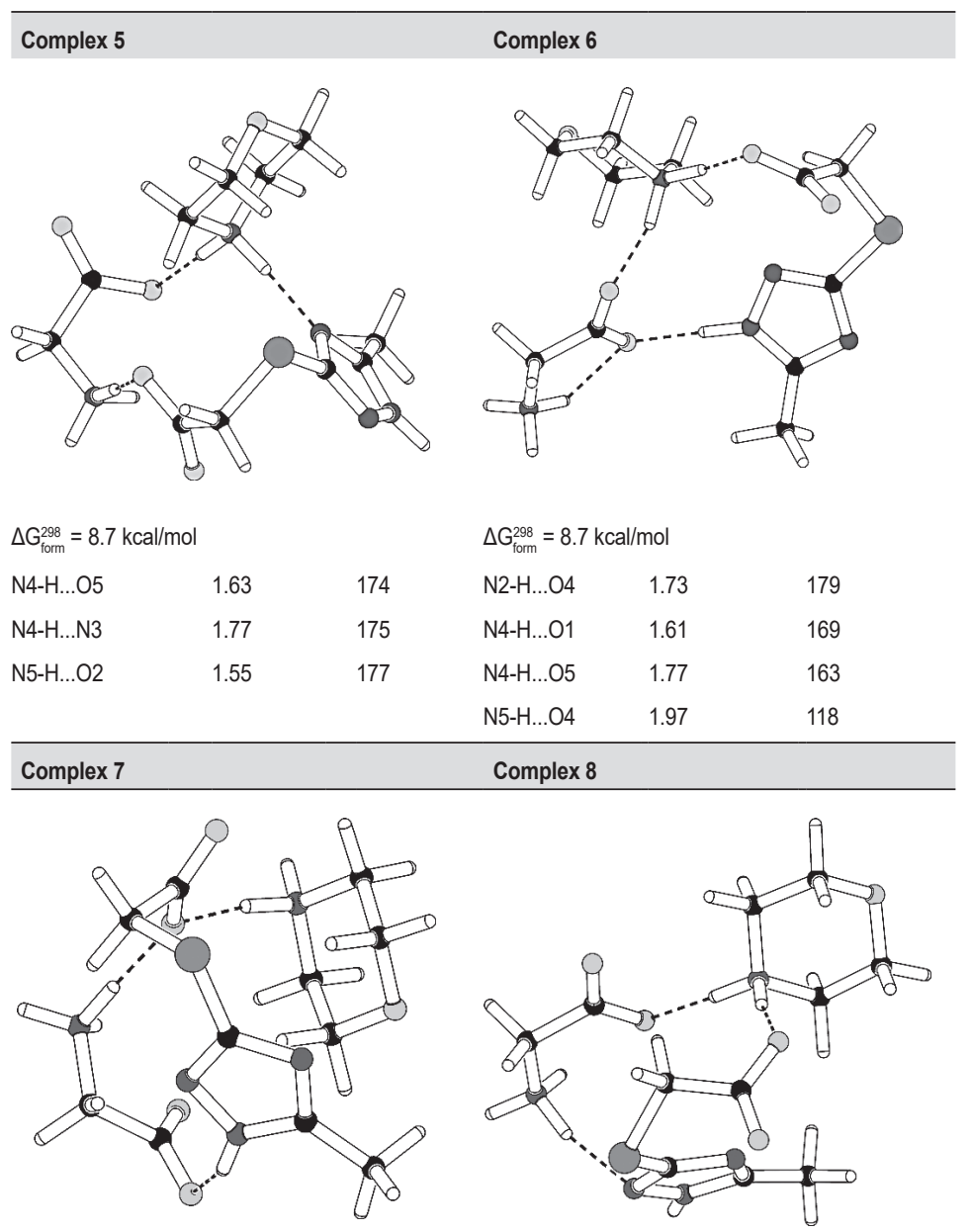

$\Delta \mathrm{G}_{\mathrm{form}}^{298}=8.8 \mathrm{kcal} / \mathrm{mol}$

\begin{tabular}{llllll} 
N2-H...05 & 1.80 & 157 & N4-H...01 & 1.62 & 172 \\
N4-H...01 & 1.62 & 171 & N4-H...04 & 1.69 & 178 \\
N5-H...01 & 1.67 & 171 & N5-H...N3 & 1.83 & 167 \\
\hline Complex 9 & & & Complex 10
\end{tabular}
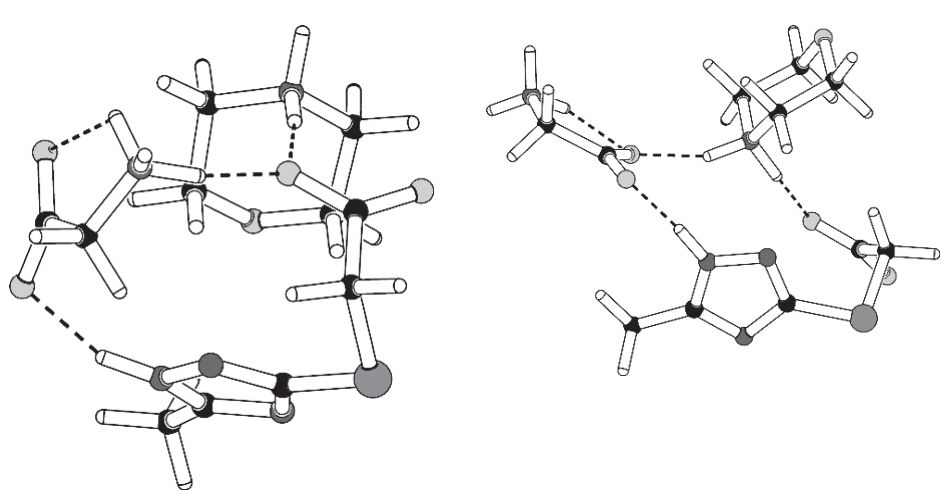

\section{$\Delta \mathrm{G}_{\text {form }}^{298}=9.2 \mathrm{kcal} / \mathrm{mol}$}

$\begin{array}{lll}\text { N2-H...O5 } & 1.71 & 172 \\ \text { N4-H...O4 } & 1.78 & 157 \\ \text { N4-H...O1 } & 1.60 & 165 \\ \text { N5-H...O4 } & 1.94 & 119\end{array}$

Quantum-chemical modeling of the complexes of thiatriazoline and glycine has shown the possibility of the formation of multiple hydrogen bonds in them (Table 1). However, it is worth noting that the number of hydrogen bonds in MTTA complexes with glycine (3-4) is less than in MTTA complexes with arginine (5-7) [14]. Perhaps this is due to the smaller size of the amino acid that is involved in the complexing. Furthermore, the energy of 10 the most stable complexes with glycine is in the range 6.6-9.2 $\mathrm{kcal} / \mathrm{mol}$, which is somewhat higher than it was designed for MTTA arginine complexes [14].

A detailed analysis of intermolecular interactions in 10 most stable three-component complexes made it possible to discover a lot of regularities. All selected complexes can be divided into two groups. The first group may include complexes of $1,5,6,8$ and 10 , in which each of the molecules is associated with the other two (Fig. 3), and in the complexes of the second group $(2,3,4,7$ and 9$)$ where glycine and MTTA are linked by two hydrogen bonds, forming a dimer, and the protonated morpholine molecule is bound by only one hydrogen bond to the deprotonated carboxyl group of MTTA.

The second observed regularity concerns the glycine molecule. Although glycine is the simplest and smallest amino acid, it tends to form an intramolecular charge-assisted hydrogen bond between the protonated amino group and the carboxylate anion. Such intramolecular hydrogen bond is realized in the six most stable complexes out of ten, regardless of the group to which these complexes belong. It should be noted that the glycine molecule with an intramolecular hydrogen bond has two free proton donors and two proton acceptors which are capable of intermolecular binding. Comparison of the structure of the most stable complexes allows us to state that these glycine sites participating in intermolecular interactions are equivalent.

The MTTA molecule contains a deprotonated carboxyl group that participates in the formation of intermolecular hydrogen bonds in all analyzed complexes and a triazole ring that can act as both proton donor and acceptor. At the same time, an additional charge is not localized on the atoms of the triazole ring, so hydrogen bonds with its participation are noticeably weaker.

One of the features of the complexes under consideration is the fact that the protonated molecule of morpholine participates in hydrogen bonds only as a proton donor, despite the presence of an oxygen atom capable of being an acceptor.

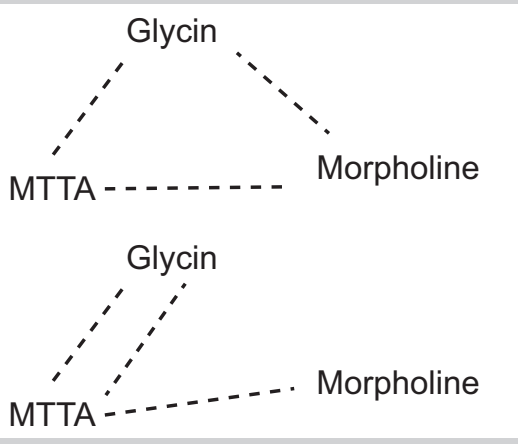

Fig. 3. Two types of binding in the studied three-component complexes. 
The results of calculations show that the multiplicity of charge-assisted donor and acceptor sites for hydrogen bonding leads to the formation of complexes that are different in structure but close in energy formation. It can be assumed that this causes the relative thermodynamic instability of studied complexes in solution. This means that solvation of individual molecules is much more beneficial than solvation of complexes.

It should also be noted that solvation energies were calculated in the approximation of infinite dilution. In solutions of a finite concentration, greater stability of molecular complexes should be expected.

\section{Conclusions}

The conducted quantum-chemical study of three components (MTTA, morpholine and glycine) system has shown the possibility of three-component complexes formation with low stability in infinitely dilute solutions. It should be noted that the formed complexes can be divided into two types: trimeric and dimeric + morpholine. The glycine molecule tends to form not only intermolecular hydrogen bonds, but also a charge-enhanced intramolecular hydrogen bond. It can be expected that in real solutions the enhancement of intermolecular interactions can lead to an increase in the stability of the complexes.

\section{References}

[1] Khizhyak, A. A., \& Kursov, S. V (2003) Uchastie vozbuzhdayushchikh aminokislotnukh transmitterov $v$ mekhanizmakh nejrodestrukcii i perspektivnye metody patogeneticheskoj korrekcii [Participation of excitatory amino acid transmitters in mechanisms of neurodestruction and promising methods of pathogenetic correction]. Bil, zneboliuvannia, intensyvna terapiia, 1, 43-46. [in Ukrainian].

[2] Zubatyuk, R. I., Kucherenko, L. I., Mazur, I. A., Khromyleva, O. V., \& Shyshkin, O. V. (2014) Teoreticheskoe isledovanie stroeniya kompleksov izoniazida s tiotriazolinom [Theoretical study of the structure of complexes with isoniazid Thiotriazoline]. Himiya geterociklicheskikh soedinenij, 3, 476-482. [in Russian].

[3] Trott, O., \& Olson, A. J. (2010) Software news and update AutoDock Vina: Improving the speed and accuracy of docking with a new scoring function, efficient optimization, and multithreading. J. Comput. Chem., 31, 455-461. doi: 10.1002/jcc.21334.

[4] Stewart, J. J. P. (2012) MOPAC2012. Colorado Springs, CO: Stewart Computational Chemistry, USA.

[5] Grimme, S. (2006) Semiempirical GGA-type density functional constructed with a long-range dispersion correction. J. Comput. Chem., 27(15), 1787-1799. doi: 10.1002/jcc.20495.

[6] Grimme, S., Antony, J., Ehrlich, S., \& Krieg, H. (2010) A consistent and accurate ab initio parametrization of density functional dispersion correction (DFT-D) for the 94 elements H-Pu. J. Chem. Phys, 132(15), 154104. doi: 10.1063/1.3382344

[7] Grimme, S., Ehrlich, S., \& Goerigk, L. (2011) Effect of the damping function in dispersion corrected density functional theory. J. Comput. Chem, 32(7), 1456-1465. doi: 10.1002/jcc.21759.

[8] Weigend, F., \& Ahlrichs, R. (2005) Balanced basis sets of split valence, triple zeta valence and quadruple zeta valence quality for $H$ to $R n$ : Design and assessment of accuracy. Phys. Chem. Chem. Phys, 7(18), 3297-3305. doi: 10.1039/b508541a.

[9] Kruse, H., \& Grimme, S. (2012) A geometrical correction for the interand intra-molecular basis set superposition error in Hartree-Fock and density functional theory calculations for large systems. J. Chem. Phys., 136(15), 154101. doi:10.1063/1.3700154.

[10] Marenich, A. V., Cramer, C. J., \& Truhlar, D. G. (2009) Universal solvation model based on solute electron density and on a continuum model of the solvent defined by the bulk dielectric constant and atomic surface tensions. J. Phys. Chem. B, 113(18), 6378-6396. doi:10.1021/jp810292n.

[11] Neese, F. (2012) The ORCA program system. Wiley Interdiscip. Rev. Comput. Mol. Sci., 2(1), 73-78. doi: 10.1002/wcms.81.

[12] Shishkina, S. V., Zubatyuk, R. I., Kucherenko, L. I., Mazur, I. A., \& Shishkin, O. V. (2009) Two polymorphs of morpholin-4-ium 2-(5-methyl-1H-1,2,4-triazol-3-ylsulfanyl)acetate Acta Crystallographica Section C, C65, 024-026. doi: 10.1107/S0108270108042042.
[13] Dawson, A., Allan, D. R., Belmonte, S. A., Clark, S. J., David, W. I. F., McGregor, P. A., et al. (2005) Effect of High Pressure of the Crystal Structures of Polymorphs of Glycien Cryst.Growth Des., 5(4), 1415-1427. doi: $10.1021 / \mathrm{cg} 049716 \mathrm{~m}$.

[14] Kucherenko, L. I., Khromyleva, O. V., Mazur, I. A., \& Shishkina, S. V. (2017) Theoretical study of L-arginine + thiotriazolin complexes formation. Zaporozhye medical journal, 1(100), 108-112. doi: http://dx.doi.org/10.14739/2310-1210.2017.1.91736.

\section{Information about authors:}

Kucherenko L. I., Dr.hab., Professor, Head of the Department of Pharmaceutical Chemistry, Zaporizhzhia State Medical University, Vice-President of SPA “Farmatron”, Zaporizhzhia, Ukraine.

Hromyleva O. V., Ph.D., Senior Lecturer, the Department of Pharmaceutical Chemistry, Zaporizhzhia State Medical University, Ukraine.

Mazur I. A., Dr.hab., Professor, the Department of Pharmaceutical Chemistry, Zaporizhzhia State Medical University,

President of SPA “Farmatron”, Zaporizhzhia, Ukraine.

Shishkina S. V., Ph.D., analyst at SPA “Farmatron”, Zaporizhzhia, Ukraine.

\section{Відомості про авторів:}

Кучеренко $\Lambda$. І., А-р фарм. наук, професор,

зав. каф. фармацевтичної хімії, Запорізький Аержавний меАичний університет, віце-презиАент НВО "Фарматрон", Запоріжжя, Україна.

Хромильова О. В., канА. фарм. наук, старший викладач каф. фармацевтичної хімії, Запорізький державний медичний університет, Україна.

Мазур І. А., А-р фарм. наук, професор каф. фармацевтичної хімії, Запорізький Аержавний медичний університет, президент HВО «Фарматрон", Запоріжжя, Україна.

Шишкіна С. В., канА. хім. наук, аналітик НВО “Фарматрон”, м. Запоріжжя, Україна.

\section{Сведения об авторах:}

Кучеренко А. И., А-р фарм. наук, профессор, зав. каф. фармацевтической химии, Запорожский государственный медицинский университет, вице-президент НПО "Фарматрон", Запорожье, Украина.

Хромылёва О. В., канд. фарм. наук, старший преподаватель каф. фармацевтической химии, Запорожский государственный медицинский университет, Украина.

Мазур И. А., А-р фарм. наук, профессор каф. фармацевтической химии, Запорожский госуАарственный меАицинский университет, президент НПО "Фарматрон", Запорожье, Украина. Шишкина С. В., канА. хим. наук, аналитик НПО "Фарматрон", г. Запорожье, Украина.

\section{Конфлікт інтересів: віАсутній.}

Conflicts of Interest: authors have no conflict of interest to declare.

Надійшло Ао редакції / Received: 19.04.2017

Після Аоопрацювання / Revised: 24.04.2017

Прийнято Ао Аруку / Accepted: 28.04.2017 